\title{
Determinants of the Real Equilibrium Exchange Rate in Albania: An Estimation Based on the Co-Integration Approach
}

\author{
Natasha Ahmetaj*, Merita Bejtja \\ Bank of Albania
}

\author{
Article history: \\ Received: \\ $28 / 03 / 2019$ \\ Revised: \\ Accepted: \\ $08 / 05 / 2019$ \\ $10 / 06 / 2019$ \\ Published:

\begin{abstract}
Problem/Relevance: Investigation of exchange rate behaviour has been an important topic in international monetary economics because of the impact of exchange rates on economies. One strand of the literature has focused on explaining the observed movement of the nominal or real exchange rate in terms of macroeconomic variables. Another strand of the literature has evaluated the behaviour of the real exchange rates in relation to the equilibrium exchange rate, which is the real exchange rate that is consistent with macroeconomic balances. Albania implements a free floating exchange rate regime; therefore, evaluating whether the actual real exchange rate is too strong or too weak compared with the real equilibrium exchanges rate has great relevance for the Albanian economy.
\end{abstract}

Research Objective/Questions: Generally, the real exchange rate is defined as the nominal exchange rate adjusted for the relative price differential between domestic and foreign goods and services. So, an appreciation of the nominal exchange rate or higher inflation at home relative to other countries may lead to an appreciation of the real exchange rate. Such appreciation weakens the competitiveness of a country, widens the current account deficit and increases vulnerability to financial crises. The opposite holds true when the real exchange rate depreciates. The aim of this paper is, first, to estimate the equilibrium real exchange rate for the Albanian currency against the euro and, second, to assess the total exchange rate misalignment during the period of 2001Q1-2017Q1. Thus, the equilibrium real exchange rate is used as a benchmark for evaluating the misalignment of the actual real exchange rate.

Methodology: This paper explores the determinants of the real exchange rate for Albania, during the period of 2001Q1-2017Q1, based on the stock-flow approach, the so-called Behavioural Equilibrium Exchange Rate (BEER), which effectively employs reduced-form modelling of the exchange rate based on standard co-integration techniques. The stock of net foreign assets and productivity changes has been considered fundamental for the real exchange rate. We have used the Johansen co-integration technique to test the existence of long-run relationships between our main variables and to evaluate the path of the equilibrium real exchange rate based on vector error correction model (VECM) results. Then the analysis is completed by calculating the degree of misalignment as the difference between the actual real exchange rate and the equilibrium real exchange rate.

Major Findings: Based on the Johansen co-integration approach, we find one long-run relationship between the real exchange rate of the Albanian lek against the euro, relative productivity and net foreign assets during the period of 2001Q1 to 2017Q1. The model implies that the real exchange rate is affected, as we expected, by relative productivity and net foreign assets, confirming that an increase in both variables leads to an appreciation of the real exchange rate in the long run. Our results show that the behaviour of the actual real exchange rate is similar to the path of the equilibrium exchange rate and that the degree of misalignment throughout the period is estimated to be moderate.

Implications: Our empirical results confirm that the degree of misalignment is reasonable, suggesting a consistency between macroeconomic (especially monetary) policies and the free floating exchange rate regime. Assessing real

* Corresponding author.

E-Mail address:nahmetaj@,bankofalbania.org 
exchange rate misalignment is a very important issue for policy makers because of the severe welfare and efficiency costs that such misalignment can have for an economy.

JEL Classification: C22, F31, F32

Keywords: Equilibrium exchange rate, Co-integration analysis, BEER

\section{Introduction}

The exchange rate is a very important economic variable, especially for a small, open economy such as Albania, due to the effect that it may have on the country's competitiveness, trade and current account, inflation, wages, domestic economic activity and bank stability. Thus, assessing the equilibrium exchange rate is an important responsibility of macroeconomic policymakers (Isard, (2007)).

The equilibrium exchange rate is usually used as a benchmark for evaluating whether the actual exchange rate is too strong or too weak. Thus, the equilibrium exchange rate can be defined as the real exchange rate level whereby the economy maintains internal and external balances. Internal balance means that factors of production, such as labour and capital, are being fully utilized, so prices and wages are stable and the economy is running at normal capacity. This implies that the output gap is zero and unemployment is at the non-accelerating inflation rate of unemployment (NAIRU). Internal balance is a necessary but not sufficient condition to ensure that the real exchange rate is at equilibrium. The equilibrium exchange rate is achieved when the rest of the world is in equilibrium, so the external balance can be characterized as a state of stable net foreign assets.

The equilibrium real exchange rate is not an ambiguous concept in the literature. A large number of equilibrium exchange rate concepts have been proposed (Driver and Westaway (2004), Hinkle and Montiel (1999), and MacDonald and Stein (1999)), which try to explain the equilibrium of the exchange rate at different time horizons, based on different approaches. We will focus our analysis on the estimation of the equilibrium exchange rate in the case of Albania, based on the stock-flow approach proposed by Clark and Macdonald, (1998), Faruqee, (1995); and Alberola et al., (1999), among others. This approach allow us to estimate a long-run equilibrium exchange rate for lek/euro in Albania between the real exchange rate and fundamental variables, by employing the advantages of the Vector Error Correction Model (VECM).

Our results show the existence of a co-integrating relationship among real exchange rate, net foreign assets to GDP ratio, and relative productivity. Moreover, we have compared the actual real exchange rate and the equilibrium exchange rate derived from the model, and our result shows that the actual path of the exchange rate is in line with the equilibrium exchange rate derived from the model, over the last 15 years.

The paper is structured as follows: Section 2 provides an overview of the theoretical literature on real exchange rate determinants. In Section 3, we present the methodology and the main data that we have used to estimate the equilibrium exchange rate. Results are discussed in Section 4 and, in Section 5, we conclude.

\section{Literature review}

Understanding exchange rate behaviour remains a relevant issue when it comes to current monetary economics. But, related economic thoughts and literature are divided into two main strands. In the first strand, observed fluctuations of the real and nominal exchange rate are 
considered in relation to economic variables that may influence it. The second strand aims at assessing the exchange rate relative to economic fundamentals and drawing conclusions on whether the local currency is properly positioned against other hard currencies.

One of the most commonly accepted approaches to identify determinants of the equilibrium real exchange rate stems from the Purchasing Power Parity (PPP) theory first developed by Gustav Cassel (1918). Following the relative PPP viewpoint, the equilibrium real exchange rate tends to remain constant in the long run but misalignments in the real exchange rate are caused when the change in relative prices is different from the degree of fluctuation in the nominal exchange rate. However, economists have tested the PPP theory, pursuing criticisms on the accuracy of this paradigm vis-a-vis the long-run behaviour of the real exchange rate. Studies from Froot and Rogoff (1991) and MacDonald (1995) look at it from this perspective. Under continuous scrutiny, both theoretically and empirically, the PPP theory is generally understood to be able to, at best, determine the real exchange equilibrium only in the very long horizon, which typically overcomes relevant timeframes for economic policy and cannot provide an understanding of factors behind short and mid-term deviations from equilibrium.

The non-stationarity of real exchange rates and the slow pace of convergence toward the PPP-projected equilibrium path have been the main underlying factors behind the design and elaboration of new approaches to identify shorter-term equilibriums of the exchange rate. Williamson (1985) developed a novel methodology for the time in estimating the calculation of what is now widely identified as the Fundamental Equilibrium Exchange Rate (FEER). The equilibrium exchange rate, defined as the real effective exchange rate in FEER by the author, is consistent with the macroeconomic balance and this is commonly interpreted as an economy operating amid full employment and low inflation with a current account that is sustainable. This exchange rate concept is denoted as "fundamental" in that it abstracts from short-term factors and emphasizes instead determinants that are important over the medium term. Driver and Westaway (2004) conclude that the exchange rate is regarded to be in its medium-term equilibrium when the economy has reached its internal and external balances, but asset stocks may still be changing. However, from this approach, the exchange rate remains constant as long as the positions of internal and external balances are unchanged, not taking into account behavioural analysis. Moreover, the FEER framework assumes that there are no restrictions on trade and capital flows in the economy (Cline \& Williamson, 2010). Because of this, the macroeconomic balance approach has additional difficulties in estimating exchange rate alignments in developing countries like Albania, where capital and goods markets are underdeveloped, governments can heavily intervene in the exports and imports and there are capital flow controls. These factors have strong effects on current account balances.

The Behavioral Equilibrium Exchange Rate approach (BEER) was introduced as a cointegration-based view by Clark and Macdonald in their paper in 1998 and was considered to be an advancement in studying the equilibrium exchange rate. In the BEER, the exchange rate equilibrium is determined by a group of properly-selected explanatory variables, which includes the fundamental factors in the FEER approach, such as productivity growth, as well as other factors that affect the behaviour of the actual exchange rate in medium or short run, such as monetary policy. In general, the BEER is estimated using the Johansen's co-integration analysis. Differences between the multiple empirical applications of this approach consist mainly in the exchange rate determinants considered. These variables are usually selected on an ad-hoc basis and are motivated by different theories of determining the exchange rate, often including the Balassa-Samuelson productivity hypothesis, the uncovered interest rate parity theory and/or the assets model developed by Frenkel and Mussa (1980). Compared to FEER, the BEER provides more flexibility in the selection of variables where the incorporation of short-term factors in the model framework makes it capable of capturing the dynamic behaviour of the exchange rate 
equilibrium and co-integration techniques. Application of the VECM makes it more powerful and convenient for empirical studies.

This empirical study utilizes the stock-flow approach to define the exchange rate equilibrium in Albania. The main motivation for choosing this approach is that we are able to capture any short-run fluctuations in the movement of the real exchange rate. This represents what is, indeed, observed in reality and it has been used by different authors over time in exchange rate analytical contexts, such as Faruqee (1995); Alberola et al. (1999), Chen and Rogoff (2002); MacDonald (2002); MacDonald and Ricci (2003); Égert, Halpern and MacDonald (2006); Alberola and Navia (2007), Cashin et al. (2012);. On the whole, this theoretical model, which encompasses the balance of payments and Balassa-Samuelson approaches to the real exchange rate determinants, depends on a very limited set of fundamentals: the stock of net foreign assets and productivity differentials. Hinkle and Montiel (1999) have applied similar applications for developing economies. Using co-integration techniques, Alberola et al. (1999) conclude that net foreign assets and developments in sectoral prices are the fundamental factors underlying the behaviour of the real exchange rate for major currencies as well as for a panel of currencies of EU member countries. While most of the literature on transition economies focuses on productivity gains as a key determinant of real exchange rate movements, the role of the portfolio theory appears less clear. On the same path as empirical methodologies for estimating the equilibrium exchange rate in developing countries, as mentioned earlier in this paper, Egert, Halpern and MacDonald (2006) have conducted comprehensive research on the equilibrium exchange rate in the countries of Central, Eastern and South-Eastern Europe, and have concluded that no precise assessment can be made because of model uncertainty as well as fundamentals. The opposite conclusion is found by research studies on emerging economies (Burgess et al. (2003); Lomatzsch and Tober (2002)), suggesting that higher net foreign assets are accompanied by exchange rate depreciation. In the case of Albania, following a similar empirical path, Vika and Luçi (2011) conclude that regardless of the set of controlling variables used, there is little evidence that the RER in Albania is significantly misaligned from the mid-term equilibrium path based on productivity differentials and net foreign assets.

\section{Methodology}

We employ a VECM proposed by Johansen $(1988,1992)$ to estimate the long-run relationship between the real exchange rate and the potential fundamental factor of the real exchange rate in Albania. This approach allows us to estimate the magnitude and significance of the effect of each independent variable on long-term fluctuation of the real exchange rate.

A VECM is a restricted Vector Autoregressive model VAR, which is designed for times series that are non-stationary but they are cointegrated. Co-integration means that despite being individually non-stationary, a linear combination of two or more series can be stationary. So there is a long-run or equilibrium relationship between them (Gujarati, (2004)). -The VECM is built on the long run or co-integration relationship between variables while allowing for short-run adjustment dynamics toward this long run equilibrium. Our model is specified as follows, where the real exchange rate lek/euro is expressed as a function of main macroeconomic variables.

$$
\Delta R E R_{i_{t}}=\beta_{0}+\alpha_{i}\left(R E R_{i_{t-1}}+\sum_{i=1}^{p-1} \beta_{i} X_{i_{t-1}}\right)+\sum_{i=1}^{p=1} \beta_{j} \Delta X_{i_{t-1}}++\varepsilon_{i_{t}}
$$

Where, $\Delta$ is the difference operator, $\beta_{0}$ is a vector of constant terms, $\beta_{i}$ and $\beta_{j}$ are the matrices of the coefficients measuring the long-run and short-run lagged effect of variables on each other, the $\alpha_{i}$ parameter measures the speed of adjustment of the $i$-th endogenous variable towards the 
equilibrium, $\varepsilon_{t}=\left[\varepsilon_{s t}, \varepsilon_{b t}\right]$ is the vector of error terms and $\varepsilon_{t} \sim i i d\left(0, \sigma^{2}\right) ; X_{i t}$ is a vector of $\kappa$ observable endogenous variables used to explain the main real exchange rate drivers, such as ratio of net foreign assets to GDP, real interest rate differential and productivity differentials between Albania and the euro area. The advantages of the VECM approach developed by Johansen and Juselius (1990) are threefold. First, this approach provides a long-run cointegration relationship through the model's specification of cooperation among short-run effects. Second, the method assumes the existence, in the long-run, of a co-integration relationship among the variables of interest's order of integration I(1). Finally, it enables estimation of the long and the short-run effects, simultaneously.

\section{Data}

Quarterly data covering the period from 2001 Q1 to 2017 Q1 are used to estimate the VEC model. Precise definitions of the variables can be found in the table below.

Table 1: Description of the main data

\begin{tabular}{|c|c|c|}
\hline Variable & Definition & Source \\
\hline RER & $\begin{array}{l}\text { This variable is defined as the logarithm of the } \\
\text { ALL/EUR real exchange rate, adjusted for } \\
\text { consumer prices. An increase of this variable } \\
\text { indicates lek depreciation. }\end{array}$ & Bank of Albania \\
\hline PROD & $\begin{array}{l}\text { This indicator tends to capture the relative } \\
\text { productivity between Albania and the euro area. } \\
\text { Relative Productivity is measured as the ratio of } \\
\text { nontradables'price index to tradables' price } \\
\text { index for Albania vis-à-vis the EU. Nontradables } \\
\text { price index is proxied with Consumer Price } \\
\text { Index, while tradable price index is proxied with } \\
\text { the Producer Price Index. }\end{array}$ & $\begin{array}{l}\text { Bank of Albania, Instat, } \\
\text { European Central Bank }\end{array}$ \\
\hline NFA & $\begin{array}{l}\text { This variable captures the ratio of net foreign } \\
\text { assets to GDP. }\end{array}$ & $\begin{array}{l}\text { Bank of Albania, European } \\
\text { Central Bank. }\end{array}$ \\
\hline $\begin{array}{l}\text { Real Interest rate } \\
\text { differential or spread }\end{array}$ & $\begin{array}{l}\text { This variable is calculated as the difference } \\
\text { between the real interest rate in Albania and the } \\
\text { euro area. }\end{array}$ & $\begin{array}{l}\text { Bank of Albania, Instat, } \\
\text { European Central Bank }\end{array}$ \\
\hline
\end{tabular}

In Graph 1, we present the performance of the main determinants of the real exchange rate in Albania from 2001-2017. 


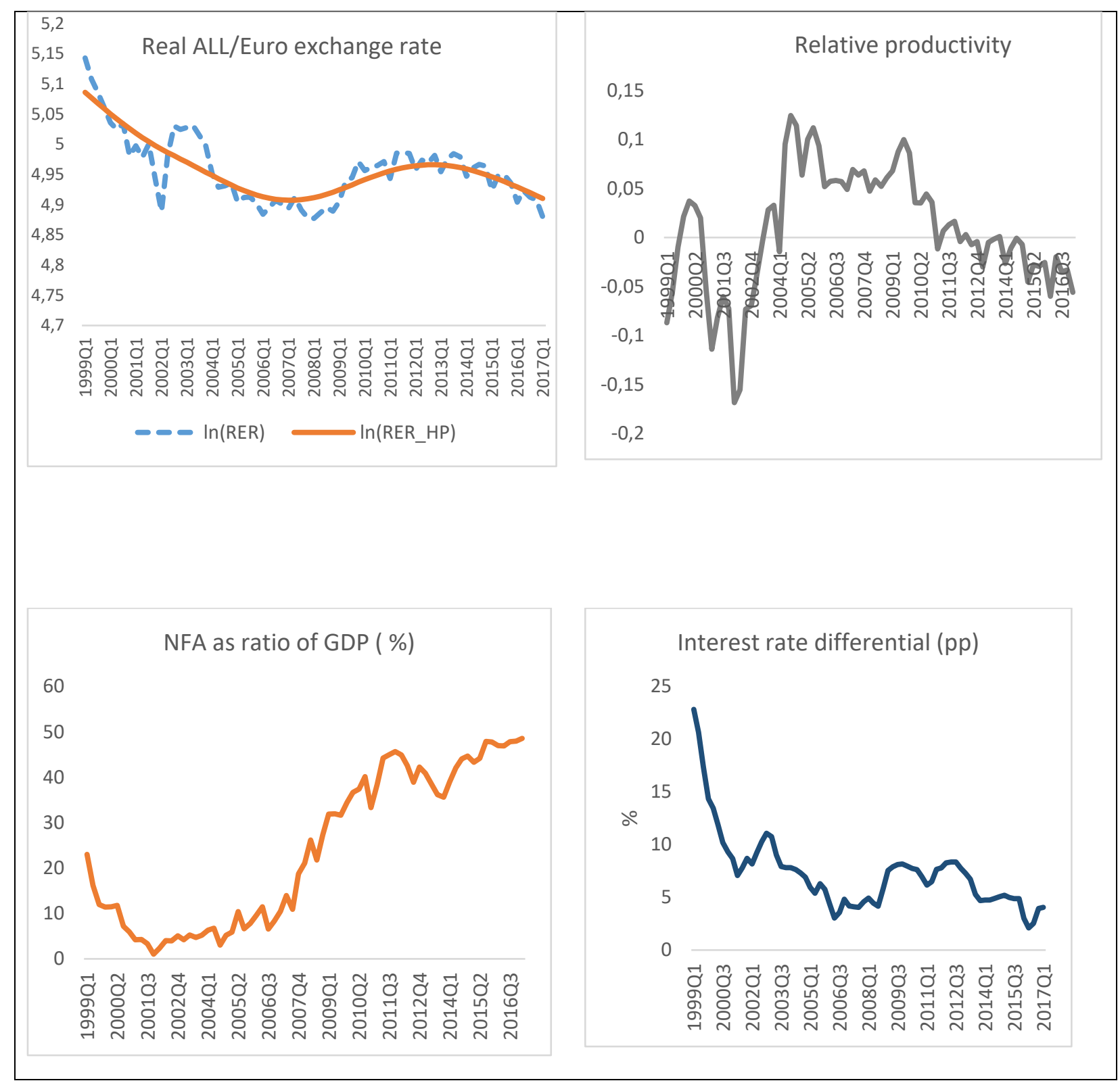

Source: Bank of Albania, Instat, ECB, author calculation

Graph 1: Real ALL/EUR exchange rate and the determinants of the Equilibrium Real Exchange Rate

\section{Results}

There are various methods to test for co-integration among variables. We have employed a widely-used co-integration technique based on Johansen (1991), which requires that our economic variables be integrated of order I (1). This entails a test for the unit root in time series before proceeding to the co-integration analysis. Table 2 displays the unit-root testing based on augmented Dickey-Fuller and Phillips-Perron tests. For the period of 2001Q1 to 2017Q1, both tests indicate that the hypothesis of a unit root for variables in level series cannot be rejected, but stationarity can be achieved when variables are transformed in first difference. 
Table 2: Unit root test results

\begin{tabular}{lll}
\hline & $\begin{array}{l}\text { Level series } \\
(\mathrm{p} \text {-values })\end{array}$ & $\begin{array}{l}\text { First Difference series } \\
(\mathrm{p} \text {-values })\end{array}$ \\
\hline \multirow{2}{*}{ RER } & -1.907 & $\mathbf{- 5 . 4 3 8 ^ { * * * }}$ \\
& $(0.326)$ & $(0.000)$ \\
NFA & -0.562 & $\mathbf{- 5 . 0 6 8 2 ^ { * * * }}$ \\
& $(0.8708)$ & $(0.0001)$ \\
PROD & -1.639 & $\mathbf{- 6 . 3 2 8 ^ { * * * }}$ \\
& $(0.456)$ & $(0.000)$ \\
\hline
\end{tabular}

Note: Figures in bracket represent $\mathrm{p}$-values associated with the test

The estimated results confirm that all series are found to be stationary in first difference. The lag structure was determined using the LR test and the FPE (Final prediction error). The appropriate lag length criteria based on the above test is 2 (Table 3). Furthermore, the JarqueBera test and Langrage Multiplier test show that the residuals have a normal distribution and are not correlated. These tests assure that the estimated VAR model is correctly specified.

Table 3: Test of lag length criteria

\begin{tabular}{lll}
\hline Lag & $\begin{array}{l}\text { LR ( sequential modified LR test } \\
\text { statistic) }\end{array}$ & $\begin{array}{l}\text { FPE ( Final prediction } \\
\text { error) }\end{array}$ \\
\hline 1 & 464.80 & $1.13 \mathrm{e}-10$ \\
2 & $36.94^{*}$ & $9.42 \mathrm{e}-11^{*}$ \\
3 & 25.82 & $9.46 \mathrm{e}-11$ \\
4 & 21.39 & $1.02 \mathrm{e}-10$ \\
\hline
\end{tabular}

* indicates lag order selected by the criterion

Having found that our variables are integrated of order I (1), in the Johansen co-integration test we assume that there is an intercept (but no deterministic trend) in the co-integrating equation, and no intercept in the VAR part. We have also added a measure of interest rate disparity as an exogenous variable (proxied by the spread in $2 \mathrm{Y}$ government bonds rates between Albania and the euro area), which helped to improve the coefficient of determination. Based on the Trace and the Maximum Eigenvalue tests (as shown in Table 4), it is evidenced that there is only one cointegrating equation at the 0.05 level.

Table 4: Results from Johansen cointegration test

\begin{tabular}{lllll}
\hline & \multicolumn{2}{l}{ Trace statistic } & \multicolumn{2}{l}{ Maximun eigenvalues statictic } \\
\hline & $\mathrm{Ho}=\mathrm{r}$ cointegrating equation & \multicolumn{2}{l}{ Ho=r cointegration equation } \\
& $\mathrm{r}=0$ & $\mathrm{r} \leq 1$ & $\mathrm{r}=0$ & $\mathrm{r} \leq 1$ \\
Number of cointegrating vectors & 36.15 & 11.89 & 24.257 & 7.97 \\
& $(0.0393)$ & $(0.4582)$ & $(0.0263)$ & $(0.4241)$ \\
\hline
\end{tabular}

Note: Figures in bracket represent p-values associated with the test. 
Table 5 displays the long-run relationship of the real exchange rate of lek with relative productivity and net foreign assets. The parameters of both explanatory variables have the expected sign and are statistically significant, indicating that a rise in either variable would cause an appreciation of the Albanian lek against the euro, in real terms. The speed of adjustment to equilibrium is also shown to be relatively fast, as shown by the coefficient on the error correction term of around -0.52 . This finding is similar with previous empirical results by Vika \& Luçi (2011) and Hoda (2012) for Albania and suggest that the lek/euro real exchange rate adjusts to its longrun equilibrium path fairly quickly.

Table 5: Results for VEC model - long-run relationship

\begin{tabular}{lll}
\hline & Coefficient & t-statistics \\
\hline RER & 1 & \\
PROD & $-0.26^{* *}$ & $(3.167)$ \\
NFA & $-0.063^{* * *}$ & $(2.098)$ \\
constant & $4.83^{* * *}$ & $(-227)$ \\
$\begin{array}{l}\text { Estimate of the speed of adjustment based } \\
\text { on the cointegrating equation for the RER }\end{array}$ & -0.52 & $(-5.039)$ \\
& & \\
\hline
\end{tabular}

Note: Figures in bracket represent t-statistics associated with the test.

Moreover, in Table 6, we present the variance decomposition of the equilibrium exchange rate based on the estimated results presented in Table 5. The variance decomposition indicates the forecast error variance of the real exchange rate, which can be explained by exogenous shocks to net foreign assets, relative productivity and real exchange rate. The estimated results show that, over the horizons of four quarters or one year, $81 \%$ of the movement of the exchange rate is explained by its own movement, $18 \%$ by relative productivity and $1 \%$ by net foreign assets as a ratio of GDP. Over a four-year horizon (sixteen quarters) $49.8 \%$ of the variation of the exchange rate is explained by its own movement, $47 \%$ by relative productivity and only $3 \%$ by the variation of the NFA.

Table 6: Variance decomposition of RER

\begin{tabular}{|c|c|c|c|}
\hline \multicolumn{4}{|c|}{ Variance Decomposition of RER } \\
\hline Period (quarters) & RER & PROD & NFA \\
\hline 1 & 100.00 & 0.00 & 0.00 \\
\hline 2 & 94.76 & 4.78 & 0.47 \\
\hline 3 & 87.15 & 11.88 & 0.97 \\
\hline 4 & 81.08 & 17.60 & 1.32 \\
\hline 5 & 76.46 & 21.97 & 1.57 \\
\hline 6 & 72.59 & 25.63 & 1.78 \\
\hline 7 & 69.18 & 28.85 & 1.97 \\
\hline 8 & 66.12 & 31.74 & 2.13 \\
\hline 9 & 63.37 & 34.35 & 2.29 \\
\hline
\end{tabular}




\begin{tabular}{llll}
\hline \multicolumn{2}{l}{ Variance Decomposition of RER } & & \\
Period (quarters) & RER & PROD & NFA \\
\hline 10 & 60.87 & 36.70 & 2.42 \\
11 & 58.61 & 38.84 & 2.55 \\
12 & 56.55 & 40.79 & 2.66 \\
13 & 54.66 & 42.58 & 2.76 \\
14 & 52.92 & 44.22 & 2.86 \\
15 & 51.32 & 45.73 & 2.95 \\
16 & 49.84 & 47.13 & 3.03 \\
\hline
\end{tabular}

From the long-run relationship described in Table 5, we have calculated the equilibrium of the exchange rate. This is done by applying the estimated coefficient of the cointegration relationship on the determinants of the exchange rate equilibrium in Albania. The results are presented in Graph 2. Generally, the difference between the actual real exchange rate and the estimated equilibrium exchange rate is required to exceed \pm 2 times the estimated standard deviation before one concludes that a currency is significantly over or undervalued. Our results show that the behaviour of the actual real exchange rate is similar to the path of equilibrium exchange rate. We estimate that the degree of misalignment measurement is estimated to be moderate.

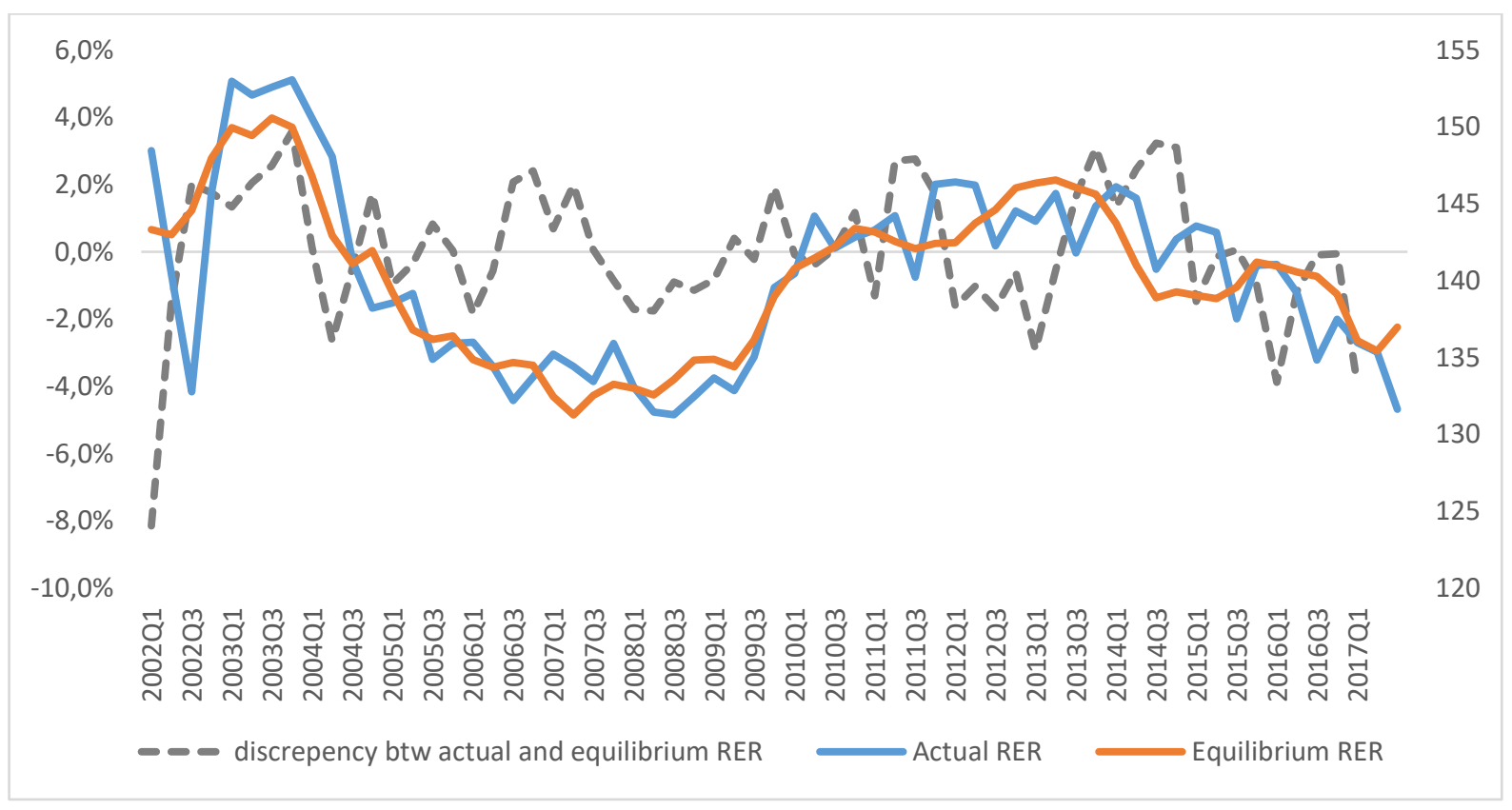

Graph 2: RER in Albania

\section{Conclusions}

In literature, the real exchange rate is used in diverse contexts and there are different definitions related to the concept of the real exchange rate equilibrium. One of the most general definitions states that the real exchange rate measures the price of domestic goods relative to the price of 
foreign goods. Furthermore, it determines the competitiveness of prices and impacts decisions of the economic agents on consumption and production, thus affecting trade, economic activity, unemployment and inflation. So, the variability of the exchange rate as well as its consequences have been the subject of much theoretical and empirical research. Two main dimensions of the variability are identified: first, exchange rate volatility, which is measured as the change of exchange rate from one point of time to another; and, second exchange rate misalignment, which measures deviation of the exchange rate from it equilibrium value (Williamson (1985), William et al. (2010)).

This paper explores the determinants of the real exchange rate in Albania during the period of 2001Q1-2017Q3 in order to derive an estimation for the long-run equilibrium exchange for the Albanian lek and to calculate the exchange rate misalignment. The choice of potential explanatory factors was based on the stock-flow approach proposed by Alberola et al. (1999), while the empirical investigation methodology is based on VECM approach.

The real exchange rate serves as a shock absorber in the economy but, in the long run, the equilibrium real exchange rate will be affected only by permanent or real shock. In our model, we have considered two main determinants to derive the equilibrium real exchange rate for Albanian lek against the euro, the evolution of relative productivity and net foreign assets. The empirical results suggest that, during the period 2001Q1-2017Q1, net foreign assets and relative productivity have been the main drivers of the real exchange rate against the euro in the long run. Moreover, based on variance decomposition we find that, in the short run (in the first year), the deviation of the real exchange rate is explained mostly by its own movements. In addition, we have calculated the misalignment of the actual real exchange rate from the equilibrium level. We find that, during the 2001Q1-2017Q1 period, the behavioural of the real exchange rate has been in line with the equilibrium exchange rate. The estimated results show the degree of misalignment of the ALL/EUR exchange rate is moderate. This confirms the fact that there is little evidence that real exchange is significantly misaligned from the equilibrium, based on the development of relative productivity and net foreign assets. Furthermore, these results confirm the consistency between macroeconomic policies and the free-floating exchange rate regime in Albania.

Finally, our empirical results contribute to filling the gap in the empirical literature in developing countries, like Albania, and this estimation can be used as a tool for monitoring exchange rate developments. In addition, taking into account the advantages of VECM, this approach can be used to explain not only the misalignment from the equilibrium, but also exchange rate volatility in the short run.

\section{References}

Alberola, E., \& Navia, D. (2007). Equilibrium exchange rates in the new EU members: external imbalances vs. real convergence. Banco de Espana, Documentos de Trabajo No.0708

Alberola, E., Cervero, S. G., Lopez, H., \&Ubide, A. (1999). Global equilibrium exchange rates: euro, dollar, "ins", "outs", and other major currencies in a panel cointegration framework. IMF Working Papers 99/175

Burgess, R., Fabrizio, S., \& Xiao, Y. (2003). Competitiveness in the Baltics in the Run-Up to EU Accession. IMF Country Report No. 114

Cashin, P., Cespedes, L., \& Sahay, R. (2002). Developing Country Real Exchange Rates: How Many are Commodity Countries? IMF Working Paper 02/223

Chen, Y-C., \& Rogoff, K. (2002). Commodity Currencies and Empirical Exchange Rate Puzzles. IMF Working Paper 02/27

Clark, P.B., MacDonald, R. (1998).Exchange Rates and Economic Fundamentals: A Methodological Comparison of BEERs and FEERs. IMF Working Paper 98/67

Driver, R. L., Westaway, P.F. (2004). Concepts of equilibrium exchange rates. Bank of England, Working Paper no. 248 
Égert, B., Halpern, L., \& MacDonald, R. (2006), Equilibrium exchange rates in transition economies: Taking stock of the issues. Journal of Economic Surveys Vol. 20, No. 2

Faruqee, H. (1995). Long-run determinants of the real exchange rate: a stock-flow perspective. IMF Staff Papers, Vol. 42 (March), 80-107

Frenkel, J.A., \& Mussa, M.L. (1980). The Efficiency of Foreign Exchange Market and Measures of Turbulence. American Economic Review 10, May, 374-381

Froot, K.A., \& Rogoff, K. (1991). The EMS, the EMU, and the transition to a common currency. National Bureau of Economic Research Macroeconomics Annual

Gujarati, D.N. (2004). Basic Econometrics, Fourth Edition,

Gustav, C. (1918). Abnormal deviations in international exchanges. The Economic Journal, 28, 413-415

Hinkle, L., \& Montiel, P. (1999). Exchange Rates Misalignment: Concepts and Measurement for Developing Countries. World Bank, Washington, DC.

Hoda, B. (2012). Equilibrium Exchange Rate in a Developing Economy. Bank of Albania Working Paper, 04, (54), 2012.

Isard, P. (2007). Equilibrium Exchange Rates: Assessment Methodologies, IMF Working Paper, 07/296

Johansen, S. (1988). Statistical Analysis of Co-integrating Vectors, Journal of Economic Dynamics and Control, 12(2), 231-254

Johansen, S. (1991). Estimation and Hypothesis Testing of Co-integrating Vectors in Gausian Vector Auto regression Models, Econometrica, 59(3), 551-580

Johansen, S. (1992), Determination of Co-integrated Rank in the Presence of a Linear Trend, Oxford Bulletin of Economics and Statistics, 54(3)

Johansen, S., \& Juselius, K. (1990). Maximum Likelihood Estimation and Inference on Co-integration-with Applications to the Demand for Money, Oxford Bulletin of Economics and Statistics, 52, 169-210

Lommatzsch, K., \& S. Tober (2002). What is behind the real appreciation of the accession countries' currencies? An investigation of the PPI-based real exchange rate. Presented at Exchange Rate Strategies during the EU Enlargement. Budapest. 27 - 30 November

MacDonald, R. (1995). Asset Market and Balance of Payments Characteristics: An Eclectic Exchange rate Model for the Dollar, Mark and Yen. IMF Working Paper 95/55

MacDonald, R. (2002). Modelling Long-Run Real Effective Exchange Rate of the New Zealand Dollar. Australian Economic Papers, Vol. 41, pp. 519-537

MacDonald, R., \& Ricci, L. (2003). Estimation of the Equilibrium Real Exchange Rate for South Africa. IMF Working Paper 03/44

MacDonald, R., \& Stein, J.L. (1999). Equilibrium exchange-rates, Kluver Academics Publisher, Boston.

Vika, I., \& Luçi, E. (2011). The equilibrium real exchange rate of lek vis-à-vis euro: Is it much misaligned? Bank of Albania Discussion Papers Series

Williamson, J. (1985). The Exchange Rate System. Policy Analyses in International Economics, Vol. 5. Washington, Institute for International EconomicsCline, W., \&

Williamson, J (2010). Estimates of Fundamental Equilibrium Exchange Rates, May 2010, Policy Briefs PB10-15, Peterson Institute for International Economics.

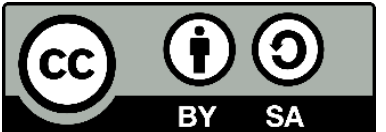

(C) 2019 by the authors. Licensee ACRN Publishing, Austria, Editor in Chief Prof. Dr. Othmar M. Lehner. This article is an open access article distributed under the terms and conditions of the Creative Commons Attribution (CC BY SA) license (https://creativecommons.org/licenses/by-sa/4.0/) 